\title{
Design And Construction Of An Expert System For Early Detection of Mental Illness in COVID-19 Patients And Handling Using Certainty Factor Method
}

\author{
Mohammad Iqbal $^{1}$, Nurfitria Khoirunnisa ${ }^{2}$ \\ ${ }^{1,2}$ Sistem Informasi, Politeknik Negeri Subang, Jl. Brigjen Katamso No. 37 (Belakang RSUD), Dangdeur, Subang
}

\begin{tabular}{l}
\hline Article Info \\
\hline Article history: \\
Received 11 07, 2021 \\
Revised 12 12, 2021 \\
Accepted 12 15, 2021 \\
\hline
\end{tabular}

\section{Keywords:}

Covid-19

Mental Illnes

Expert System

Certainty Vector

Early Detection

\begin{abstract}
Covid-19 is a new type of virus that can be transmitted to humans. This virus spreads very quickly and has spread to almost all countries. In the midst of Covid-19 outbreak, social phenomenon emerged that has the potential to exacerbate the situation, it is negative social stigma against a person or group of people who experience symptoms or have COVID-19 disease. They are labeled, stereotyped, discriminated against, and treated differently because they are associated with Covid-19 disease. This pandemic puts pressure on the emergence of mental illnesses such as fatigue, stress, fear, sadness, loneliness, schizophrenia, anxiety, depression, or post-traumatic stress disorder (PTSD) and its probability of dying from Covid 19 is almost 3 times higher than those who do not have mental illness. Therefore, an expert system is needed to detect mental disorders in Covid-19 patients early as prevention. This system works as psychologist experts detect Covid-19 patients through the people closest to the patient. By observing the conditions and symptoms arose in the patient's psychological condition, the user will fill the data in the system to find out the level of disturbance experienced by the patient in real time. Then, the system will provide solutions, diagnosis results and appropriate treatment methods for patients so that symptoms of mental disorders can be detected and prevented early on without direct contact between patients and experts.
\end{abstract}

This is an open access article under the CC BY-SA license.

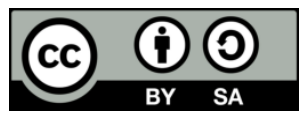

\section{Corresponding Author:}

Mohammad Iqbal

Sistem Informasi, Politeknik Negeri Subang

Jl. Brigjen Katamso No. 37 (Belakang RSUD), Dangdeur, Subang

Email: miqbaljanuar@gmail.com

(C) The Author(s) 2021

\section{Introduction}

Covid-19 is a new type of corona virus can transmitted to humans. This virus spreads very quickly and has spread to almost every country, including Indonesia[1]. As COVID-19 spreads, social phenomena emerge that can make things worse, such as social stigma or negative associations for individuals or groups who experience or suffer from COVID-19 symptoms. They are stigmatized, stereotyped, discriminated against, treated differently and/or harassed based on status because they are related to Covid-19 disease[2]. This stigma will actually trigger the spread of disease that is increasingly out of control in the community. COVID-19 pandemic has put pressure on every aspect of people's lives. Fatigue, stress, anxiety, fear, frustration[3], sadness and loneliness must be taken care of and prevented as soon as possible[4].

According to Oxford Research, 1 in 8 recovered patients infected with COVID-19 have a psychiatric or neurological complication within 6 months of testing positive for Covid-19. This finding is based on a survey of nearly 2,336,379 coronavirus patients in the United States[5]. 
In addition, a new study of approximately 7,400 people in New York, all of whom tested positive for COVID-19, found that people diagnosed with COVID-19 had schizophrenia and were nearly three times more likely to die from Covid-19 than those who did not schizophrenia. This suggests that schizophrenia makes patients more susceptible to infection with COVID-19 virus. These results suggest that schizophrenia is considered the second largest risk factor (after age) for death from Covid19 in New Yorkers[6]. And according to Gracia Ivonika, M.Psi. psychologists from several mental health studies of Covid-19 survivors found that some of them had experienced conditions such as anxiety, depression, or post-traumatic stress disorder (PTSD)[7][8].

In Indonesia, the handling of Covid-19 focuses on physical health, only a few describe the mental health status of patients. Though mental health conditions should also be a concern at this time. There have been four cases of Covid-19 patients who committed suicide in Indonesia in four different isolation centers. When examining these cases, hospitals must effectively provide psychological assistance to patients. It is important to provide timely and effective psychological counseling to patients who believe that they must be responsible for transmitting the disease to those around them[9].

Therefore we need an expert system that can detect early mental illness (mental disorders) of Covid19 patients as a prevention of more serious mental disorders. This system works as psychologist experts detect Covid-19 patients who have symptoms of mental illness through the people closest to the patient[10]. By paying attention and observing the conditions and symptoms arose in the patient's psychological condition, someone as the user in this system (family, nurse, doctor or psychologist) will fill the data to find out how much disturbance the patient is experiencing. After that, the system will provide solutions, diagnosis results and appropriate treatment methods for patients so that symptoms of mental disorders can be detected and prevented early on without direct contact between patients and experts (contactless).

Based on the information from the observations, the researcher compiled this scientific work with the title "Design And Construction Of An Expert System For Early Detection of Mental Illness in Covid-19 Patients And Handling Using Certainty Factor Method" as a solution to mental illness owned by Covid-19 patients so that patients can be given action precise and fast.

\section{Research Method}

Prototyping is an approach method in systems development where a program is designed quickly step by step for user evaluation directly. The prototype offers users an overview of the system to be developed [11]. Some of the advantages of using a prototyping model are as follows:

1. User-designed replication for an ideal system.

2. Can be added and shortened according to user requests even though the system development process is running.

3. Saves resources and time.

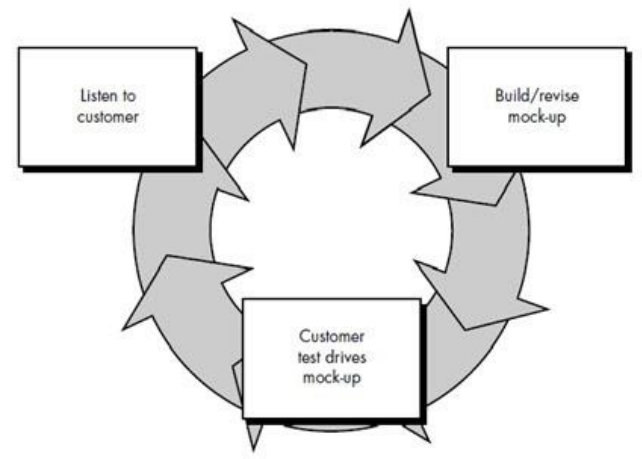

Figure 1. Prototyping Model[12]

The picture shows three phases in the development of information systems using the prototyping method [13]. The first step is to listen to customers or communicate to listen to user needs. Developers and users together determine the concept of the system to be developed. There are two steps in communication processing. First, the developer makes direct observations of the system to run by the user. The developer must be able to include the user's point of view, its to be heard the user liked and to find flaws in the system used. Second, the next step is the communication process, it is the interview. Developers conduct interviews with users about

Jurnal Teknologi dan Open Source, Vol. 4, No. 2, December 2021: 216 - 226 
complaints of the system used and the user's need to get out of the problem. The result of the communication step is a conceptual solution proposed by the developer. The communication step is the step of analyzing and defining system requirements [14].

Referring to the data has been obtained in the first step, the next step for the developer is the build/revise mockup or modeling step quickly 7 . In this step, the developer designs of the develope functionality design and develope of system interface design. The result of this step is prototype, which is an initial version of a system to represent concepts, designs and find more problems and possible solutions [15].

The last step is customer test drive mockup step. In this step the prototype is sent to the user to be tested for feasibility. This test is designed with a view to collecting user feedback and making improvements if deficiencies are found.

\section{Result and Discussion}

The Expert System for Early Detection of Mental Illness in Covid-19 Patients and its Handling Using the Certainty Factor Method works as psychologist experts can monitor and detect Covid-19 patients who have symptoms of mental illness through the people closest to the patient such as family, relatives, nurses/doctors who can see directly and observe the patient's behavior patterns. The people closest to this patient will enter data on the patient's behavior and habits in the expert system so that mental illness symptoms can be detected and diagnosed quickly to treat patient immediately.

\section{A. Listen to Customer/Interview}

Data collection methods used are interviews and literature study. Interviews were conducted with resource persons who work as doctors and nurses to obtain information about mental illness in Covid-19 patients. Then heritage studies are carried out to collect information about research, they are through journals, research papers and other relevant sources.

\section{B. Build or Revise Mockup}

In the build or revise mockup step, the developer realizes the interface design as visualization of the form of the system to be developed, as the result, the developer can measure the level of user satisfaction and can immediately correct it if an error or deficiency is detected.

The method used in designing this system is the certainty factor method. Certainty factor is a method to prove the uncertainty of an expert's thinking [16], where to accommodate this one usually uses a certainty factor to describe the level of expert confidence in the problem at hand [17]. There are two ways to get the level of confidence from a rule, namely by using the 'Net Belief' method and by interviewing an expert.

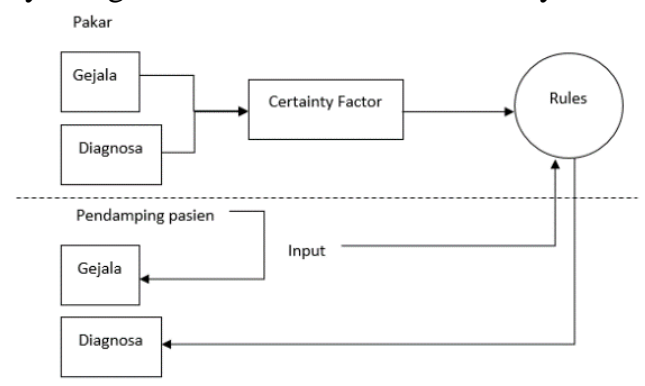

Figure 2. Flowmap of an expert system using Certainty Factor[18]

An expert system to detect patients' mental disorders early and provide solutions by applying the Certainty Factor (CF) method [19]. In this method, the user will select the symptoms according to the patient's experience, then the system will check one by one the symptoms selected by the user with the appropriate rules according to the user's input. The system will provide output into the diagnosis of mental disorders experienced by patients, solutions and appropriate treatment methods for patients so that symptoms of mental disorders can be detected and prevented early on without direct contact between patients and experts (contactless) [20].

In the implementation of an expert system for diagnosing mental disorders in children, this formula will use: $\mathrm{CF}[\mathrm{CF} 1, \mathrm{CF} 2]=\mathrm{CF} 1+\mathrm{CF} 2 *(1-\mathrm{CF} 1)$.

Information :

Jurnal Teknologi dan Open Source, Vol. 4, No. 2, December 2021: 216 - 226 
$\mathrm{CF}=$ Certainty Factor in hypothesis $\mathrm{H}$ is influenced by fact $\mathrm{E}$. The CF value of each premise or symptom is a value given by an expert with supporting literature.

To determine the explanation of the confidence factor from the expert, it is seen from the CFcombine by referring to the interpretation table (term) certainty factor [17]. The table of evidence values from the level of confidence can be seen in Table 1 below.

Table 1. Value of confidence level evidence [21]

\begin{tabular}{|l|c|}
\hline \multicolumn{1}{|c|}{ Uncertain Term } & CF \\
\hline Definitely Not & -1.0 \\
\hline Almost Certainly Not & -0.8 \\
\hline Probably Not & -0.6 \\
\hline Maybe Not & -0.4 \\
\hline Unknown & -0.2 to 0.2 \\
\hline Maybe & 0.4 \\
\hline Probably & 0.6 \\
\hline Almost Certainly & 0.8 \\
\hline Definitely & 1 \\
\hline
\end{tabular}

The following is an image of the algorithm for early detection of mental illness in COVID-19 patients:

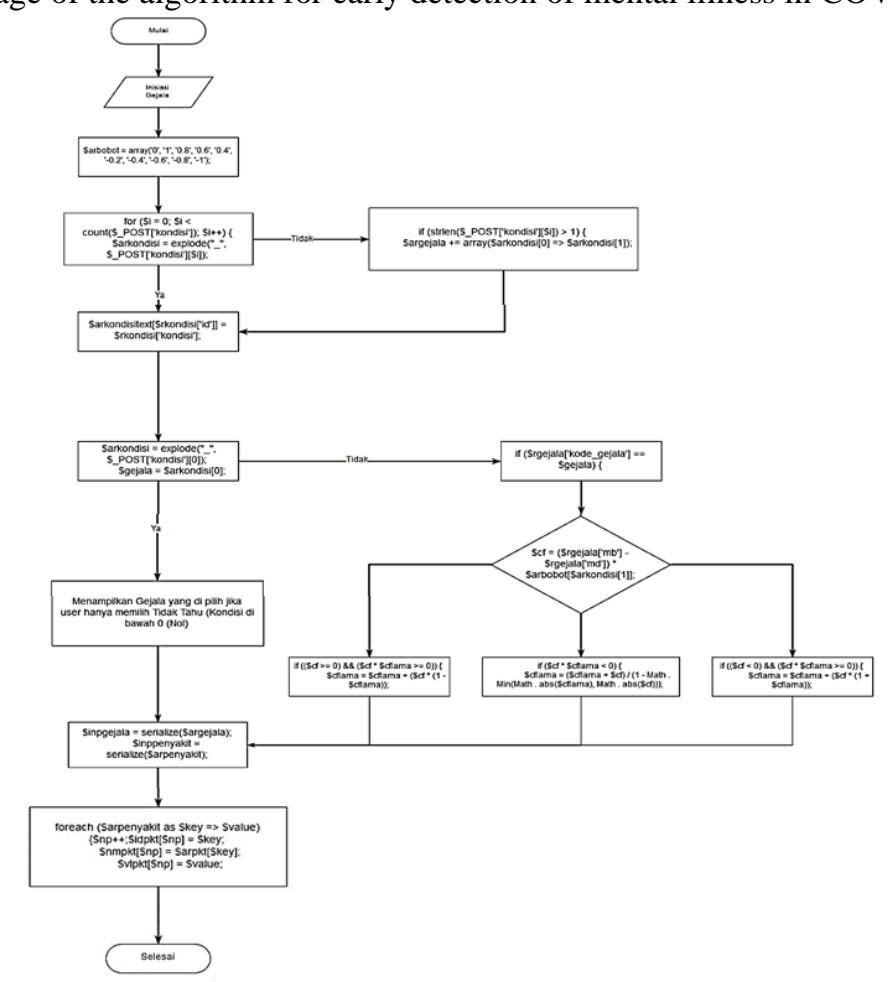

Figure 3. Mental Illness Early Detection Algorithm for Covid 19 Patients

This expert system is used to assist in the initial diagnosis of the types of mental illness (mental disorders) in Covid-19 patients so that they can be detected and prevented early and get the right treatment. To identify the type of mental illness (mental disorder) in Covid-19 patients, the system will be given the code "P01" for the first order, "P02" for the second order and so on as shown in Table 2.

Table 2. Types of Mental Illness 


\begin{tabular}{|l|l|}
\hline \multicolumn{1}{|c|}{ Code } & Type of Mental Illness \\
\hline P01 & Depression \\
\hline P02 & PTSD \\
\hline P03 & Anxiety Disorder \\
\hline P04 & Schiizofrenia \\
\hline
\end{tabular}

Based on a literature study of symptoms of mental illness, it was found that the identification of the characteristics or symptoms of mental illness in Covid-19 patients in the system, each symptom was analyzed by being given a serial number of symptoms of the disorder using the code "G01" for the first symptom sequence, "G02" for the order of symptoms second symptom and so on as in Table 3.

Table 3. Characteristics of mental illness[18]

\begin{tabular}{|c|c|c|c|c|c|}
\hline Code & Symptom & $\begin{array}{l}\text { MB P01 - } \\
\text { Depression }\end{array}$ & $\begin{array}{l}\mathrm{MB} \\
\mathrm{P} 02 \\
\text { PTSD }\end{array}$ & $\begin{array}{l}\text { MB P03 - } \\
\text { Anxiety } \\
\text { Disorder }\end{array}$ & $\begin{array}{l}\text { MB P04 } \\
\text { Schizofrenia }\end{array}$ \\
\hline G01 & Easily angry and emotional & 0.1 & 0.1 & & 0.1 \\
\hline G02 & Changeable appetite & 0.2 & & 0.2 & 0.2 \\
\hline G03 & Insomnia & 0.2 & 0.2 & 0.2 & 0.2 \\
\hline G04 & Anxious, restless and shock & 0.2 & 0.2 & 0.2 & 0.2 \\
\hline G05 & Wistful and muse & 0.1 & & 0.2 & 0.1 \\
\hline G06 & Bad Prejudice & 0.1 & & & \\
\hline G07 & Easily offended & 0.1 & & & \\
\hline G08 & Unfocused and dazed & 0.1 & 0.1 & 0.1 & \\
\hline G09 & headaches & 0.1 & & & \\
\hline G10 & Loneliness & 0.1 & & 0.1 & \\
\hline G11 & Sad all the time & 0.4 & & 0.4 & \\
\hline G12 & $\begin{array}{l}\text { Desperate and feeling } \\
\text { depressed }\end{array}$ & 0.2 & 0.2 & & \\
\hline G13 & Slow motion & 0.4 & & & \\
\hline G14 & Rampage & & 0.6 & & \\
\hline G15 & Fickle and inconsistent & & & & \\
\hline G16 & Excessive hallucinations & & 0.4 & 0.4 & 0.4 \\
\hline G17 & Feel guilty & & 0.2 & & \\
\hline G18 & Suicide Desire & & 0.6 & & 0.6 \\
\hline G19 & $\begin{array}{l}\text { Sleep disturbances such as } \\
\text { nightmares }\end{array}$ & & 0.2 & & 0.2 \\
\hline G20 & Remembering the past & & 0.6 & 0.2 & \\
\hline $\mathrm{G} 21$ & Responsive toward the past & & 0.2 & & \\
\hline G22 & Apathetic & & 0.2 & & \\
\hline G23 & Avoid social & & 0.2 & 0.2 & 0.2 \\
\hline
\end{tabular}




\begin{tabular}{|l|l|l|c|c|c|}
\hline G24 & Loss of interest & & 0.1 & & \\
\hline G25 & Post-traumatic stress disorder & & 0.2 & & \\
\hline G26 & Agitation & & & 0.2 & 0.2 \\
\hline G27 & Excessive sweating & & & 0.4 & \\
\hline G28 & Urinating too often & & & 0.2 & \\
\hline G29 & Panic attack & & & 0.2 & 0.6 \\
\hline G30 & Possessed & & & & 0.2 \\
\hline G31 & Weird Talk & & & & 0.2 \\
\hline G32 & Suspicious & & & \\
\hline
\end{tabular}

Certaity Factor Calculation :

After creating a rule, here is an example of calculation using Certainty Factor from several rules. For example, the user provides input in the form of symptoms experienced by the patient as follows:

Table 4. Examples of Patient Symptoms

\begin{tabular}{|c|c|c|c|c|c|c|c|}
\hline \multirow{2}{*}{ No } & \multirow{2}{*}{ Code } & \multirow{2}{*}{ Symptom } & \multicolumn{4}{|c|}{ Certainty Factor from Expert } & \multirow{2}{*}{$\begin{array}{c}\text { CF } \\
\text { From } \\
\text { User }\end{array}$} \\
\hline & & & P01 & P02 & $\mathrm{P} 03$ & P04 & \\
\hline 1 & G01 & Easily angry and emotional & 0.1 & 0.1 & & 0.1 & 0.4 \\
\hline 2 & G02 & Changeable appetite & 0.2 & & 0.2 & 0.2 & 0.2 \\
\hline 3 & G03 & Insomnia & 0.2 & 0.2 & 0.2 & 0.2 & 0.1 \\
\hline 4 & G05 & Wistful and muse & 0.1 & & 0.2 & 0.1 & -0.2 \\
\hline 5 & G10 & Loneliness & 0.1 & & 0.1 & & 0.6 \\
\hline 6 & G13 & Slow motion & 0.1 & & & & 0.2 \\
\hline 7 & G20 & Excessive hallucinations & 0.4 & 0.4 & 0.4 & & 0.4 \\
\hline 8 & G21 & Feel guilty & 0.2 & & & & 0.2 \\
\hline 9 & G22 & Suicide Desire & 0.6 & & 0.6 & & 0.2 \\
\hline 10 & $\mathrm{G} 27$ & Avoid social & & 0.2 & 0.2 & 0.2 & 0.1 \\
\hline
\end{tabular}

Calculating the value of Cfuser with CFexpert :

$$
\mathrm{CF}[\mathrm{H}, \mathrm{e}]=\text { Cfuser } * \text { Cfpakar }
$$

Table 5. Calculate the value of expert CF with user CF

\begin{tabular}{|l|l|}
\hline \multicolumn{1}{|c|}{ Depresi } & \multicolumn{1}{c|}{ PTSD } \\
\hline $\mathrm{CF}[\mathrm{H}, \mathrm{e} 1]=0.4 * 0.1=0.4$ & $\mathrm{CF}[\mathrm{H}, \mathrm{e} 1]=0.4 * 0.1=0.4$ \\
$\mathrm{CF}[\mathrm{H}, \mathrm{e} 2]=0.2 * 0.2=0.4$ & $\mathrm{CF}[\mathrm{H}, \mathrm{e} 3]=0.2 * 0.2=0.4$ \\
$\mathrm{CF}[\mathrm{H}, \mathrm{e} 3]=0.1 * 0.2=0.2$ & $\mathrm{CF}[\mathrm{H}, \mathrm{e} 20]=0.4 * 0.4=0.16$ \\
$\mathrm{CF}[\mathrm{H}, \mathrm{e} 5]=-0.2 * 0.1=-0.2$ & $\mathrm{CF}[\mathrm{H}, \mathrm{e} 27=0.1 * 0.2=0.2$ \\
\hline
\end{tabular}




\begin{tabular}{|l|l|}
\hline $\mathrm{CF}[\mathrm{H}, \mathrm{e} 10]=0.6 * 0.1=0.6$ & \\
$\mathrm{CF}[\mathrm{H}, \mathrm{e} 13]=0.2 * 0.1=0.2$ & \\
$\mathrm{CF}[\mathrm{H}, \mathrm{e} 20]=0.4 * 0.4=0.16$ & \\
$\mathrm{CF}[\mathrm{H}, \mathrm{e} 21]=0.2 * 0.2=0.4$ & \\
$\mathrm{CF}[\mathrm{H}, \mathrm{e} 22]=0.2 * 0.6=0.12$ & \multicolumn{1}{c|}{ Skizofrenia } \\
\hline \multicolumn{1}{|c|}{ Gangguan Kecemasan } & $\mathrm{CF}[\mathrm{H}, \mathrm{e} 1]=0.4 * 0.1=0.4$ \\
$\mathrm{CF}[\mathrm{H}, \mathrm{e} 2]=0.2 * 0.2=0.4$ & $\mathrm{CF}[\mathrm{H}, \mathrm{e} 2]=0.2 * 0.2=0.4$ \\
$\mathrm{CF}[\mathrm{H}, \mathrm{e} 3]=0.1 * 0.2=0.2$ & $\mathrm{CF}[\mathrm{H}, \mathrm{e} 3]=0.1 * 0.2=0.2$ \\
$\mathrm{CF}[\mathrm{H}, \mathrm{e} 5]=-0.2 * 0.2=-0.4$ & $\mathrm{CF}[\mathrm{H}, \mathrm{e} 5]=-0.2 * 0.1=-0.2$ \\
$\mathrm{CF}[\mathrm{H}, \mathrm{e} 10]=0.6 * 0.1=0.6$ & $\mathrm{CF}[\mathrm{H}, \mathrm{e} 27]=0.1 * 0.2=0.2$ \\
$\mathrm{CF}[\mathrm{H}, \mathrm{e} 20]=0.4 * 0.4=0.16$ & \\
$\mathrm{CF}[\mathrm{H}, \mathrm{e} 22]=0.2 * 0.6=0.12$ & \\
$\mathrm{CF}[\mathrm{H}, \mathrm{e} 27]=0.1 * 0.2=0.2$ & \\
\hline
\end{tabular}

\section{$\mathrm{CF}[\mathrm{CF} 1, \mathrm{CF} 2]=\mathrm{CF} 1+\mathrm{CF} 2 *(1-\mathrm{CF} 1)$}

Table 6. Combination of Manual Calculation

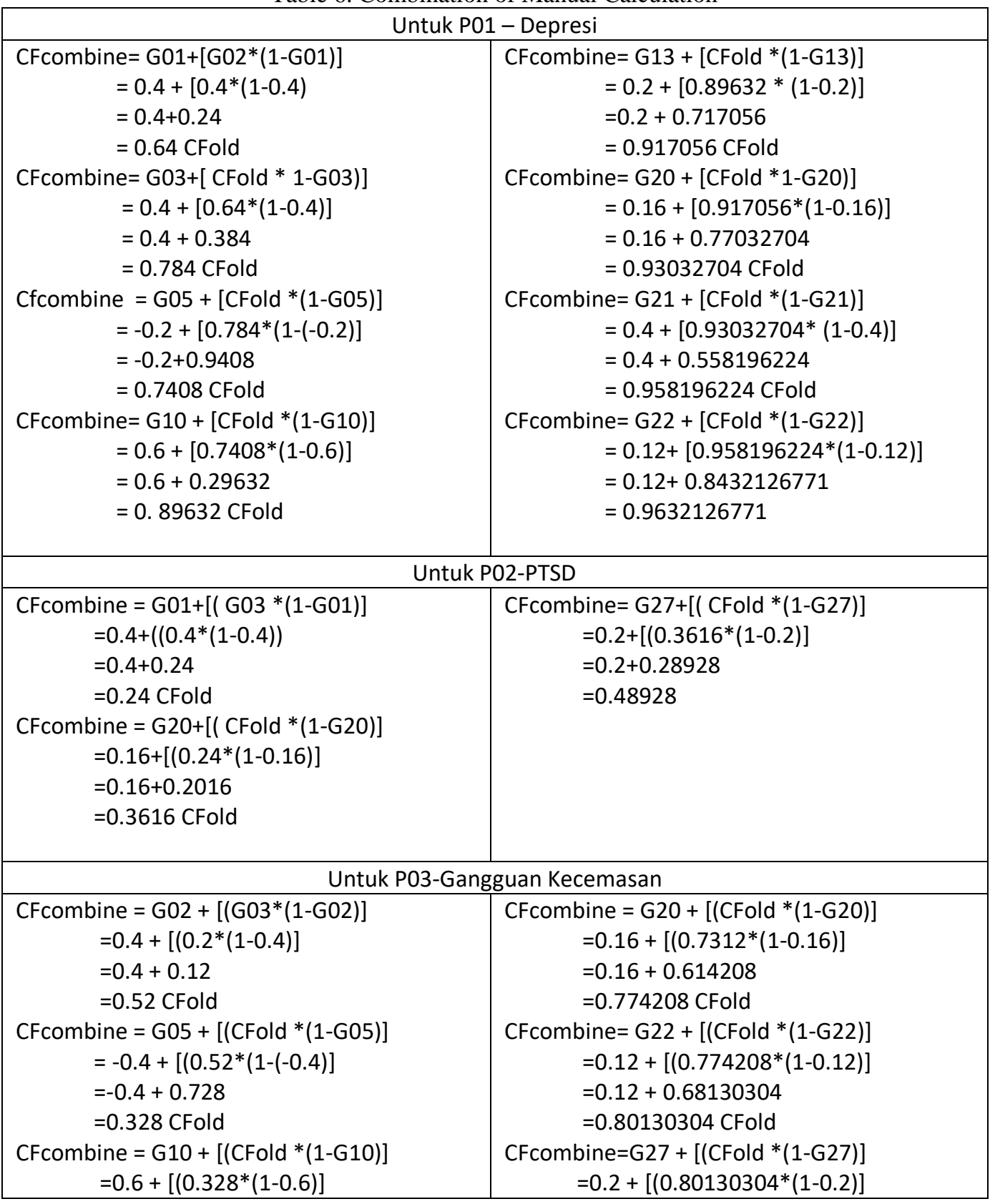




\begin{tabular}{|c|c|}
\hline $\begin{array}{l}=0.6+0.1312 \\
=0.7312 \text { CFold }\end{array}$ & $\begin{array}{l}=0.2+0.641042432 \\
=0.841042432\end{array}$ \\
\hline \multicolumn{2}{|c|}{ Untuk P04-Skizofrenia } \\
\hline 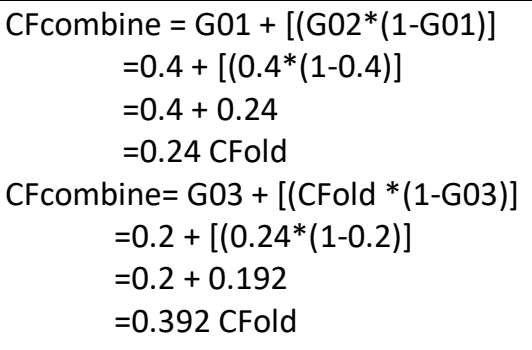 & $\begin{array}{l}\text { CFcombine }=\text { G05 }+[(\text { CFold } *(1-G 05)] \\
\quad=-0.2+[(0.392 *(1-(-0.2))] \\
=-0.2+0.4704 \\
=0.2707 \text { CFold } \\
\begin{aligned} \text { CFcombine }=\text { G } 27+[(\text { CFold } *(1-G 27)] \\
=0.2+[(0.2707 *(1-0.2)] \\
=0.2+0.21632 \\
=0.41632\end{aligned}\end{array}$ \\
\hline
\end{tabular}

From the results of the calculation of each disease $(\mathrm{P})$ then look for the largest value of the certainty value $(\mathrm{CF})$ of all mental illnesses, as follows: $\mathrm{P} 01=0.9632126771 ; \mathrm{P} 02=0.48928 ; \mathrm{P} 03=0.841042432 ; \mathrm{P} 04=0.41632$. After obtaining the largest value for each disease $(\mathrm{P})$, then: $\mathrm{P}=\max [0.9632126771,0.48928,0.841042432$, $0.41632]=0.9632126771 \times 100 \%=96.3 \%$.

From the manual calculation above, it can be concluded that the possibility of patients experiencing mental disorders, depression, and anxiety disorders. However, the biggest possibility with the percentage of $96.3 \%$ obtained is that the patient is likely to experience depression and the patient is advised to do:

Prevention:

1. Avoid the habit of being alone by looking for a good community

2. exercise regularly, at least 3-5 times a week with a duration of about 30 minutes

3. Consumption of foods with balanced nutrition and a regular diet

4. make life more relaxed and invite patients to enjoy

5. Avoid consumption of alcoholic beverages and illegal drugs.

Treatment :

1. Psychotherapy.

2. Cognitive behavior therapy (CBT). This therapy aims to help sufferers gone of negative thoughts and feelings, and replace them with positive responses.

3. Problem-solving therapy (PST), to improve the sufferer's ability to deal with experiences that trigger feelings of depression.

4. Interpersonal therapy (IPT) to help overcome problems that arise when dealing with other people.

5. Psychodynamic therapy to help sufferers understand what they are feeling and how to respond to those feelings.

6. Antidepressant drugs, such as escitalopram, paroxetine, sertraline, fluoxetine, citalopram, venlafaxine, duloxetine, and bupropion. The use of these drugs should always be under the supervision of a doctor because of the many side effects.

7. Electroconvulsive therapy (ECT) for people with depression who do not improve after being given drugs, experience symptoms of psychosis, and people who have attempted suicide.[22]

Next step is the implementation step of the interface to meet user needs in interacting with the system created. Good interface facilities will greatly assist users in understanding the process being carried out by the system so as to improve system performance [23].

1. Expert system home page

This page as the start page or main page in the form of the main display of the expert system, there is an image slider, expert system statistics in the form of total diseases, symptoms, knowledge and admin, not only that there is also a brief description of the expert system, for the detailed interface of the Expert System Home Page can be seen in Figure 4. 


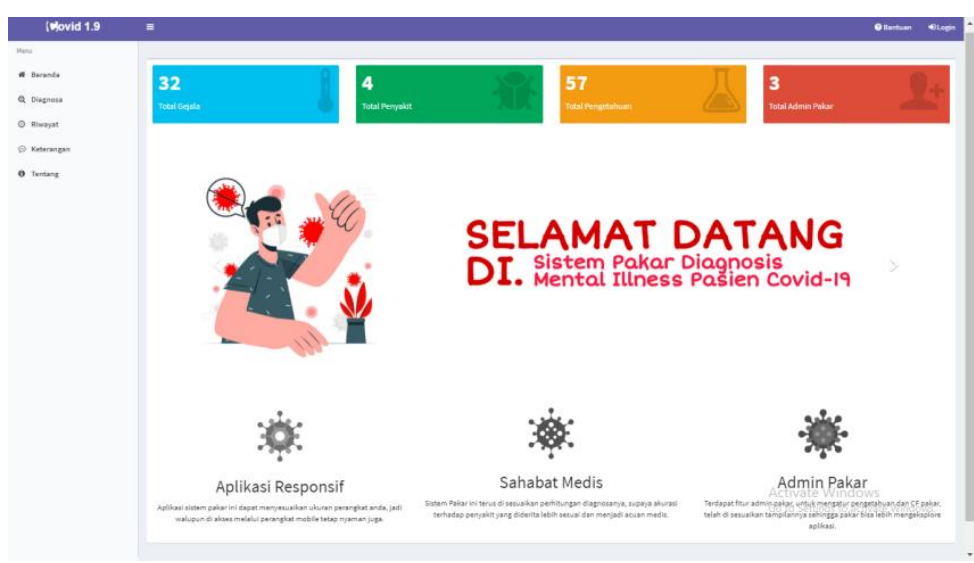

Figure 4. Home Page

\section{Expert System Diagnostic Page}

This page contains a selection of diagnoses, there is a choice of symptoms and the user must choose the symptoms found in the field and the possibilities that exist, if so, the user presses the process button, for the detailed interface of the Expert System Diagnostics Page, see Figure 5

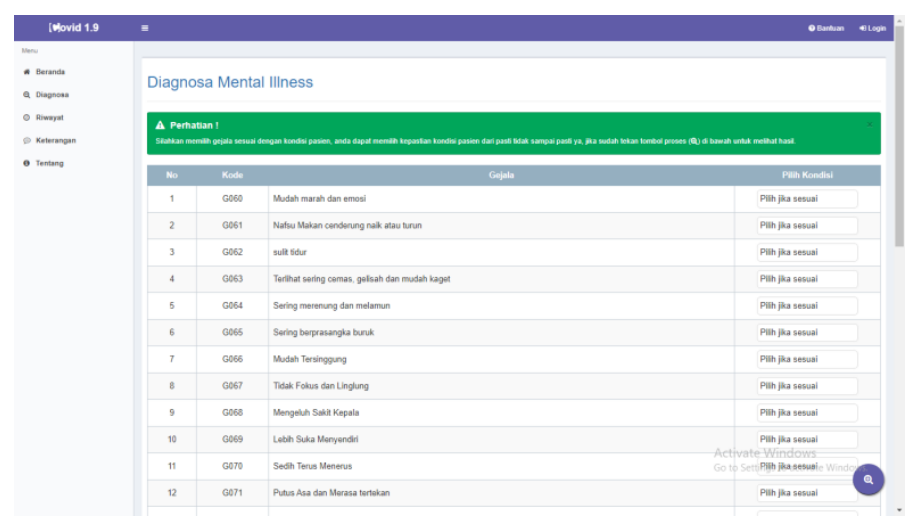

Figure 5. Diagnosis Page

\section{Diagnosis Results Page and Prevention/Treatment Suggestions}

This page is a continuation of the diagnosis page where from the results of the symptoms that have been selected, the diagnosis results will be displayed in the form of CF values and \% (percent), there are also suggestions in the form of disease prevention and treatment methods along with a brief description and values of other possible diseases if there are the same symptoms, for the details of the Diagnostic Results Page interface, see Figure 6. 


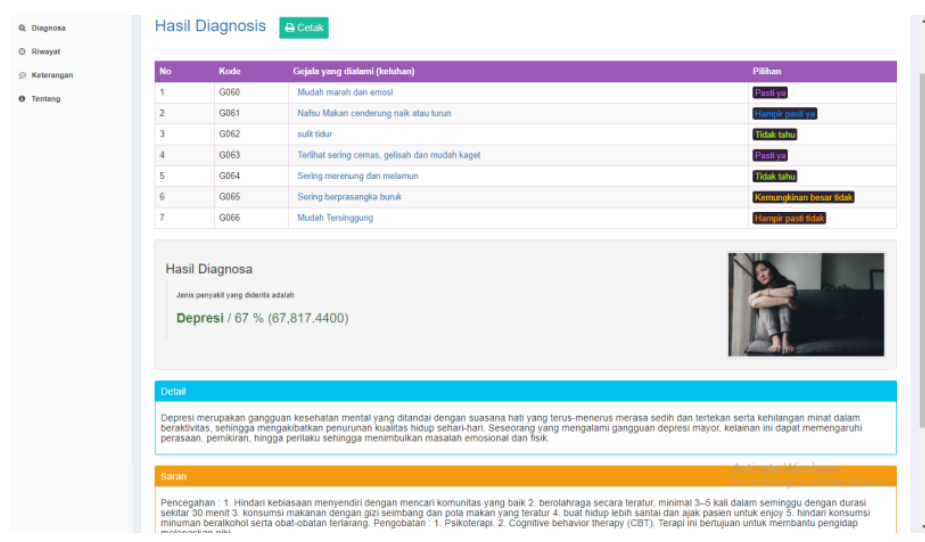

Figure 6. Diagnosis Results Page

\section{Customer Test Drive Mockup}

The last step is the customer test drive mockup. At this step, testing of this expert system is carried out. Testing is carried out through a direct experimental process using a PC or mobile phone device by asking questions to users, namely the patient's family, doctors and nurses using a questionnaire with a scale using a Likert scale. The conclusion of the results of the interview question instruments can be seen in Table 7 .

Table 7. Conclusion of User Interview Instrument Results

\begin{tabular}{|c|l|c|}
\hline No & \multicolumn{1}{|c|}{ Questions } & $\begin{array}{c}\text { Result of } \\
\text { Interview }\end{array}$ \\
\hline 1. & $\begin{array}{l}\text { In your opinion, is the appearance of the mental } \\
\text { illnes expert system website attractive? }\end{array}$ & $80 \%$ Agree \\
\hline 2. & $\begin{array}{l}\text { In your opinion, is the layout of the mental illnes } \\
\text { expert system website good enough and ideal? }\end{array}$ & $75 \%$ Agree \\
\hline 3. & $\begin{array}{l}\text { In your opinion, is this mental illnes expert system } \\
\text { website easy to use? }\end{array}$ & $75 \%$ Agree \\
\hline 4. & $\begin{array}{l}\text { In your opinion, does this mental illness expert } \\
\text { system website provide assistance and convenience } \\
\text { in properly diagnosing the mental illness of COVID- } \\
19 \text { patients? }\end{array}$ & $95 \%$ Agree \\
\hline 5. & $\begin{array}{l}\text { In your opinion, does this mental illness expert } \\
\text { system website provide advice that helps in the } \\
\text { prevention and treatment of mental illness in } \\
\text { COVID-19 patients? }\end{array}$ & $90 \%$ Agree \\
\hline 6. & $\begin{array}{l}\text { In your opinion, is this mental illness expert system } \\
\text { website really needed and needed by patient } \\
\text { families, doctors and nurses? }\end{array}$ & $95 \%$ Agree \\
\hline
\end{tabular}

\section{Conclusion}

Based on the results of research on expert systems for detecting mental illness in Covid-19 patients, the following conclusions can be drawn:

1. It has been successfully designed for early detection of symptoms of mental illness in Covid-19 patients obtained from accurate diagnosis results with an accuracy percentage of up to $90 \%$ according to the results of questionnaire conducted by designing an expert system using the certainty factor calculation method by involving doctors as experts, system journals experts and the acquisition of data sources from the field. 
2. In addition to carrying out early detection, this expert system helps provide solutions in the form of prevention and treatment for patients after making a diagnosis and getting what percentage of the possibility of experiencing mental illness so that it can be treated early.

\section{Acknowledgement}

The researcher expresses his gratitude for the main participation of Alvin Triyanto, he is a student of Subang State Polytechnic Information System study program who has assisted in writing and compiling this scientific paper to completion.

\section{References}

[1] d. M. D. C. Pane, "Virus Corona," alodokter.com, 2021. https://www.alodokter.com/virus-corona (accessed Feb. 07, 2021).

[2] Honestdoc.id, "Ciri-Ciri dan Gejala Gangguan Kecemasan (Ansietas)," honestdocs.id, 2019. https://www.honestdocs.id/gejala-gangguan-kecemasan (accessed Feb. 07, 2021).

[3] A. A. and D. A. of America, "Generalized Anxiety Disorder (GAD)," adaa, 2021. https://adaa.org/understandinganxiety/generalized-anxiety-disorder-gad (accessed May 18, 2021).

[4] A. Sajidah, "Dampak Stigma pada Kesehatan Mental di Tengah Pandemi Covid-19," kompasiana, 2020. https://www.kompasiana.com/amirahsajidah/5ebb8079d541df4120325922/dampak-stigma-pada-kesehatanmental-ditengah-pandemi-covid-19 (accessed Feb. 07, 2021).

[5] Y. Rahmawati, "Studi Oxford: 1 dari 8 Pasien Covid-19 Sembuh Alami Masalah Kejiwaan,” suara.com, 2021. https://www.suara.com/health/2021/02/01/121956/studi-oxford-1-dari-8-pasien-covid-19-sembuh-alamimasalah-kejiwaan (accessed Feb. 07, 2021).

[6] Healthline, "What Do You Want to Know about Schizophrenia," healthline.com, 2021. https://www.healthline.com/health/schizophrenia (accessed May 18, 2021).

[7] ADAA, "Post Traumatic Stress Disorder (PTSD)," adaa.com, 2021. https://adaa.org/understandinganxiety/posttraumatic-stress-disorder-ptsd (accessed May 08, 2021).

[8] B. K. Dewi, "Skizofrenia Tingkatkan Risiko Kematian Hampir Tiga Kali Lipat pada Pasien Covid-19," msn.com, 2021. https://www.msn.com/id-id/berita/other/skizofrenia-tingkatkan-risiko-kematian-hampir-tiga-kali-lipatpada-pasien-covid-19/ar-BB1dnEuS (accessed Feb. 07, 2021).

[9] U. Rahayu, "Kasus Pasien COVID-19 Bunuh Diri dan Kesehatan Mental Selama Pandemi," hellosehat.com, 2020. https://hellosehat.com/infeksi/covid19/bunuh-diri-pasien-covid-19/ (accessed Feb. 07, 2021).

[10] PPNI, "Pengertian Pasien," tintahmerah.wordpress.com, https://tintahmerah.wordpress.com/2015/06/23/pengertian-pasien/ (accessed Feb. 09, 2021).

2015.

[11] M. Iqbal and S. Rahayu, "Rancang Bangun Sistem Informasi Manajemen Job Placement Center Politeknik Negeri Subang,” J. Ilm. Ilmu dan Teknol. Rekayasa, vol. 1, no. 2, pp. 97-103, 2020, doi: 10.31962/jiitr.v1i2.28.

[12] R. C. Noor Santi, "Perancangan Interaksi Pengguna (User Interaction Design) Menggunakan Metode Prototyping," J. Tek. Inform., vol. 9, no. 2, pp. 108-113, 2018, doi: 10.15408/jti.v9i2.5599.

[13] I. Permata, "Pengertian Rancang Bangun Dan Konsep Sistem Informasi," indahpermata6.blogspot.com, 2013. https://indahpermata6.blogspot.com/2013/06/pengertian-rancang-bangun-dan-konsep.html (accessed Feb. 08, 2021).

[14] A. A. Pradipta, Y. A. Prasetyo, and N. Ambarsari, "Pengembangan E-Commerce Bojana Sari Menggunakan Metode Prototype," e-Proceeding Eng., p. 1043, 2015.

[15] I. Sommerville, Software Engineering (Rekayasa Perangkat Lunak). Jakarta, 2011.

[16] A. Bella, "Sistem Pakar," pakdosen.co.id, 2020. https://pakdosen.co.id/sistem-pakar/ (accessed Feb. 08, 2021).

[17] D. J. Febrian, A., Yuni, E. \& Fitriana, Pemanfaatan Metode Certainty Factor dalam Sistem. 2018.

[18] T. S. Sambani, E. B., Yoga, A. H. \& Nova, Sistem Pakar Diagnosis Penyakit Gangguan Mental Pada Anak Menggunakan Metode Certainty Factor dan Forward Chaining Berbasis Web. Informatika. Informatika, 2020.

[19] Psychologimania, "Pengertian Deteksi Dini," psychologymania.com, 2008. https://www.psychologymania.com/2013/04/pengertian-deteksi-dini.html (accessed Feb. 09, 2021).

[20] T. S. Edi, S. B., Yoga, A. H. \& Nova, Sistem Pakar Diagnosis Penyakit Gangguan Mental Pada Anak Menggunakan Metode Certainty Factor dan Forward Chaining Berbasis Web. 2020.

[21] E. \& V. Sutojo, Dalam: Kecerdasan buatan. Yogyakarta, 2010.

[22] M. Clinic, "Depression (major depressive disorder)," mayoclinic.org, 2021. https://www.mayoclinic.org/diseasesconditions/depression/symptoms-causes/syc-20356007 (accessed May 18, 2021).

[23] M. Iqbal, S. Rahayu, and T. H. A, "Pengaruh Media Pembelajaran Berbasis Web Terhadap Minat Belajar Siswa Pada Level Smp the Influence of Web-Based Learning Media and Education Game Comparison and Scale on Students ' Levels in Junior High School,” vol. 4, pp. 1-9, 2021, doi: 10.31962/jiitr.v4i1.100. 